\title{
Statistical Analysis of Natural Radioactivity Measurements for the Soil of Marsa Alam-Shalateen Red-Sea Coast Area, Egypt
}

\author{
Ghada I. El-shanshoury and A. A. Arafat \\ Radiation Safety Department, Nuclear and Radiological Regulatory Authority (NRRA)
}

This study aims to analyze the data of soil samples from Marsa Alam-Shalateen area. The result of the study is helpful in radiological mapping of the area that has high concentrations as well as to be a baseline data for future studies. Statistical analysis is applied on thirty-three samples for measuring gamma emitting radionuclides (Th-232, Ra-226, and K-40) and calculating radiation hazard indices. This analysis is also helpful to identify the existing relationships between the radiological hazard parameters and radionuclides, and consequently assessing the health exposure implication of the public to the studied soil. In this work conventional statistical analysis (Basic statistics and Frequency histogram), and multivariate statistical analysis (Persons correlation coefficient analysis, Factor analysis and Cluster analysis) are employed. The results show that there is no potential radiological health hazard associated with the soil samples of the study area according to the world acceptable value. In addition, the radioactive elements demonstrate the complexity of minerals in soil samples. In factor analysis, the results show that the first rotated factor accounts for $57.3 \%$ of the total variance and is mainly characterized by high positive loading of concentrations of Th-232 and Ra-226. The second rotated factor accounts for $41.4 \%$ of the total variance and is mainly corresponds to high positive loading of K-40. Cluster Average linkage method indicated that the concentrations of Th-232 are more related to all radiological parameters levels than Ra-226 and K-40 concentrations. Moreover, Ra-226 concentrations follow Th-232 concentrations in terms of their correlation with the levels of the radiological parameters. While cluster Ward's linkage method analysis reveals that the concentrations of Ra-226 and Th-232 are more linked to all radiological parameters data than K-40 concentrations. Cluster analysis showed that Marsa Alam-Shelateen Road km 33 is classified as the most location that has the highest value of radiation level when compared with other studied locations.

Key Words: Radionuclides, Radiological hazard parameters, conventional statistical analysis and Multivariate statistical analysis.

\section{INTRODUCTION}

The Red Sea region is sparsely populated and not more than 5 million people are estimated to live along the coast. Jeddah, in Saudi Arabia, supports the largest population with over 2 million people (1). The adjacent land areas of the Red Sea are mostly arid, having deserted or semi-deserted regions with no major river inflow. Further, inland, the desert regions bordered by extensive mountain ranges (2). Egypt has about $700 \mathrm{~km}$ of coastline along the Red Sea proper, which is of great environmental, economical and recreational value. Commercial and subsistence fisheries provide a living for a large sector of the coastal population in Egypt (3).

The Red Sea is considered one of the most important navigation paths in the world. Its importance was increased throughout the last three decades of the twentieth century after Suez Canal opening for navigation especially for oil tankers between the Middle East and Europe. A considerable amount of international trade is transported in Egypt through the Suez Canal including radioactive materials (4). 
International Journal of Advanced Scientific and Technical Research $\quad$ Issue8 volume 1 January-February 2018 Available online on http://www.rspublication.com/ijst/index.html

ISSN 2249-9954

The major industries in the Red Sea region are oil exploration, oil production, oil processing, manufacturing industries (fertilizers, chemicals, cement), tourism, fisheries and oil related maritime transport (5). Because of the rich marine life and favorable climate, tourism has become important for many Red Sea countries, with over 1 million tourists per year expected in the future. An extensive area of the coastline was developed to accommodate the increasing flux of tourists, especially in various areas along the Egyptian coastline (2). Also in 2017 Saudi Arabia plans a huge Red Sea beach tourism project. The project will cover 50 islands and 34,000 square kilometers between the cities of Umluj and Al Wajh to attract "luxury travelers from around the globe," (6). Fisheries in the Red Sea are of considerable socio-economic importance to the Red Sea countries in terms of national food security and income generation for rural communities (2).

On the Red Sea coast, there are two main centers for phosphate ore mining: Safaga and Quseir and three shipping harbors. Phosphate ore dust spilled over into the Sea during shipping is considered as a continuous source for contaminating the Red Sea coastal environment (3) in addition to;

1- In the Gulf of Suez, the northern part of the red sea, there are about $90 \%$ of the Egyptian oil exploration and production activities, which could be a significant source of environmental contamination with technological enhanced naturally occurring radioactive materials (NORM) (3).

2- With highly intensive ship traffic, some of these ships are running by nuclear power or carrying radioactive materials, which is a source of possible accidental contamination (7).

3- Also, the study on the concentrations of heavy metal pollution in the Egyptian Red Sea, over 50 years period (1934-1984), has shown that the concentrations of most of the heavy metals has increased, due to natural pollution from hot brine pools or due to man-made pollution from oil, heavy metal mining, discharge of domestic industrial wastes and phosphate mining and transportation along the Red Sea coastal areas (8).

So, the knowledge of the concentrations and distributions of radionuclides is of interest since it provides useful information in the monitoring of environmental contamination by natural and manmade radioactivity. This information is essential to create a scientific database of the radiological base-line levels and to identify the radiological impacts of non-nuclear industries (e.g. phosphate mining, phosphate shipping and oil production activities) or any accidental contamination on the coastal region of the Red Sea.

The Egyptian government gives an attention to develop Marsa-Alam Shalatin area because it is a tourist area as well as it contains some mineral resources such as gold extracts from Sokary mine. The natural radiation level of the soil is of great importance because of the harm it causes to public as a result of the use of soil in the construction materials industry or exposure to soil during daily activities.

The coastal region of the Red Sea attracted the attention of several workers. Ahmed et al., 2006 (9) measured the activity concentrations in different basement rocks in Wadi El Gemal area. Harb et al., 2008 (10), investigated the radioactivity levels in granitic rocks along Idfu - Marsa Alam road. Yousef and Saleh, 2013 (11), found that the activity concentrations of Th-232 and Ra-226 and K-40 in cataclastic rock samples taken from Abu Rusheid area (45 km southwest of Marsa Alam). In addition, the natural background radioactivity was determined for some unconsolidated shore sediment, soil, sea water and plant samples by some researchers $(3,12-15)$. It is obvious from the studies that an attention was given to determine the natural radioactivity of the rocks, shore sediments, sea water and plant, while a little one was paid to the soil cover. Only one paper discussed the activity concentrations and distributions of gamma ray emitter radionuclides, Ra-226 (U-238 series), Th-232 series and, $\mathrm{K}-40$ in soil and assessed their possible associated hazards (16).

The objective of this work is to establish baseline statistical information of background levels of naturally occurring radionuclides due to $238 \mathrm{U}, 232 \mathrm{Th}$ series and $40 \mathrm{~K}$ present in the soil samples, collected from Marsa Alam-Shalateen area that previously published (16), and their relationship to radiological hazard parameters. 
Various statistical analysis have been carried out for the radionuclides data obtained from soil sample and for the calculated radiological hazard parameters. Conventional and multivariate statistical analysis for data treatment is performed. the analysis is established in basic statistics that based on the descriptive statistics, frequency histograms of the recorded radionuclides, Pearson's correlation coefficient for all radionuclides and radiological hazard parameters, principal component analysis and cluster analysis is carried out through two axes; the first is to identify similar characteristics between natural radioisotopes and radiological hazard parameters in the soil using cluster variables. The other axis is to identify similar characteristics between radiological hazard parameters in the soil using cluster observations.

\section{Study Area}

\section{MATERIAL AND STATISTICAL METHODS}

Marsa Alam-Shalateen area lies along the southern Red Sea coast, Egypt, $700 \mathrm{~km}$ from the capital Cairo. It is situated between latitude $23^{\circ} 07^{\prime} \mathrm{N}$ in the south, latitude $25^{\circ} 47^{\prime} \mathrm{N}$ in the north, the Red sea in the east, and the Red Sea Hills in the west. The area is rich in its natural resources, cultural heritage and archaeological sites. Wadi El Gemal, Qulan, and Abraq are important sites in the area because of their unique flora and fauna, and therefore, they have been declared as natural protectorates (17). The area runs parallel to the coast for about 370 $\mathrm{km}$. Access to the area is through a number of paved roads, such as Cairo-Halayeb international coastal road and, Idfu- Marsa Alam road. Several thousands of people live in the coastal urban regions (Marsa Alam and Shalateen cities) and as inland-Bedouin communities. The main economic activities of inhabitants are tourism, herding (camel and sheep), fishing, mining works (such as gold, antimony and phosphate), goods trading and craft productions (16). Thirty-three environmental samples from soil are collected in May 2015 from the study area for radiological analysis, Ra-226, Th-232, K-40. The Global Positioning System device (GPS, eTrex, Personal Navigator, Garmin Ltd) identifies the coordinates of all sampling points. These coordinates are converted into distances so that the start location was from Shalateen coordinates. Table 1 shows the locations and their distances $(\mathrm{Km})$ under the study area beginning from Shalateen region.

Table 1: The locations and their distances beginning from Shalateen region

\begin{tabular}{|c|c|c|c|c|c|c|c|c|c|c|c|}
\hline Observation & 1 & 2 & 3 & 4 & 5 & 6 & 7 & 8 & 9 & 10 & 11 \\
\hline $\begin{array}{c}\text { Distance } \\
(\mathrm{Km})\end{array}$ & 0 & 18 & 37 & 38 & 41 & 47 & 64 & 75 & 93 & 96 & 98 \\
\hline Area & Shalateen & $\begin{array}{c}18 \mathrm{Km} \\
\text { Shalateen- } \\
\text { Marsa } \\
\text { Alam } \\
\text { Road } \\
\end{array}$ & $\begin{array}{c}0 \mathrm{Km} \\
\text { Al- } \\
\text { Gaheliy } \\
\text { a-Abraq } \\
\text { road } \\
\end{array}$ & $\begin{array}{c}\text { Marsa } \\
\text { Homeira }\end{array}$ & $\begin{array}{c}20 \mathrm{Km} \\
\text { Al- } \\
\text { Gaheliya- } \\
\text { Abraq } \\
\text { road } \\
\end{array}$ & $\begin{array}{c}10 \mathrm{~km} \\
\text { Al- } \\
\text { Gaheliya- } \\
\text { Abraq } \\
\text { road }\end{array}$ & $\begin{array}{c}30 \mathrm{~km} \\
\text { Al- } \\
\text { Gaheliya- } \\
\text { Abraq } \\
\text { road }\end{array}$ & $\begin{array}{c}\text { Al- } \\
\text { Gaheliya }\end{array}$ & $\begin{array}{c}30 \text { km } \\
\text { Baranis- } \\
\text { Aswan } \\
\text { Road }\end{array}$ & $\begin{array}{c}5 \mathrm{~km} \\
\text { Shelateen- } \\
\text { Marsa } \\
\text { Alam } \\
\text { Road } \\
\end{array}$ & $\begin{array}{c}\text { Baranis } \\
\text { village }\end{array}$ \\
\hline Observation & 12 & 13 & 14 & 15 & 16 & 17 & 18 & 19 & 20 & 21 & 22 \\
\hline $\begin{array}{l}\text { Distance } \\
(\mathrm{Km})\end{array}$ & 99 & 100 & 105 & 112 & 127 & 145 & 155 & 156 & 183 & 195 & 197 \\
\hline Area & $\begin{array}{c}47 \text { km } \\
\text { Baranis- } \\
\text { Aswan } \\
\text { Road }\end{array}$ & $\begin{array}{c}10 \mathrm{~km} \\
\text { Baranis- } \\
\text { Aswan } \\
\text { Road }\end{array}$ & $\begin{array}{c}37 \text { km } \\
\text { Baranis- } \\
\text { Aswan } \\
\text { Road }\end{array}$ & $\begin{array}{c}20 \text { km } \\
\text { Baranis- } \\
\text { Aswan } \\
\text { Road }\end{array}$ & $\begin{array}{l}\text { Hamata } \\
\text { Village }\end{array}$ & $\begin{array}{l}\text { W. Abu } \\
\text { Ghusoon }\end{array}$ & $\begin{array}{l}\text { W. Abu } \\
\text { Ghusoon }\end{array}$ & $\begin{array}{l}\text { W.Abu } \\
\text { Ghuson }\end{array}$ & $\begin{array}{c}\text { Marsa } \\
\text { Alam- } \\
\text { Shelateen } \\
\text { Road } \\
\text { Km } 69\end{array}$ & $\begin{array}{l}\text { W. Al } \\
\text { Gemal }\end{array}$ & $\begin{array}{c}\text { W. } \\
\text { Ghadeer }\end{array}$ \\
\hline Observation & 23 & 24 & 25 & 26 & 27 & 28 & 29 & 30 & 31 & 32 & 33 \\
\hline $\begin{array}{c}\text { Distance } \\
(\mathrm{Km})\end{array}$ & 206 & 208 & 227 & 228 & 234 & 237 & 239 & 284 & 289 & 290 & 291 \\
\hline Area & W.Hafafit & $\begin{array}{c}\text { Marsa } \\
\text { Alam- } \\
\text { Shelateen } \\
\text { Road Km } \\
33 \\
\end{array}$ & $\begin{array}{l}\text { W. Um } \\
\text { Tendeba }\end{array}$ & $\begin{array}{l}10 \mathrm{~km} \\
\text { Marsa } \\
\text { Alam- } \\
\text { Idfo } \\
\text { Road } \\
\end{array}$ & $\begin{array}{c}20 \mathrm{~km} \\
\text { Marsa } \\
\text { Alam- } \\
\text { Idfo } \\
\text { Road } \\
\end{array}$ & $\begin{array}{l}30 \mathrm{~km} \\
\text { Marsa } \\
\text { Alam- } \\
\text { Idfo } \\
\text { Road } \\
\end{array}$ & $\begin{array}{c}40 \mathrm{~km} \\
\text { Marsa } \\
\text { Alam- } \\
\text { Idfo } \\
\text { Road } \\
\end{array}$ & $\begin{array}{c}\text { W. } \\
\text { Bezah }\end{array}$ & $\begin{array}{c}\text { Beside } \\
\text { Um El- } \\
\text { Rus } \\
\text { Mine }\end{array}$ & $\begin{array}{l}\text { Um El } \\
\text { Rus }\end{array}$ & $\begin{array}{l}\text { W. El- } \\
\text { Meyah }\end{array}$ \\
\hline
\end{tabular}

*W represents Wadi 
The activity concentration of ${ }^{226} \mathrm{Ra},{ }^{232} \mathrm{Th}$ and ${ }^{40} \mathrm{~K}$ in soil samples are graphed and shown in Figures 1 and 2 . The minimum activity concentrations of ${ }^{226} \mathrm{Ra}$ and ${ }^{232} \mathrm{Th}$ are recorded at $10 \mathrm{~km}$ and $20 \mathrm{~km}$ Baranis-Aswan Road (See Table 1: observations 13 and 15, respectively) while the maximum values is recorded at Marsa Alam-Shelateen Road Km 33, 10 km Al- Gaheliya-Abraq road and 47 km Baranis-Aswan Road (observations 24, 6 and 12, respectively). As well as, the minimum activity concentration of ${ }^{40} \mathrm{~K}$ are recorded at $20 \mathrm{~km}$ Baranis-Aswan Road and Marsa Alam-Shelateen Road km 69 (observations 15 and 20, respectively) while the maximum values are recorded at the seven locations. These locations are shown in Figure 2 and represented in Marsa Alam-Shelateen Road km 33, W.Abu Ghuson, W.Hafafit, Al Gaheliya, W. Ghadeer, 10 km Al-Gaheliya-Abraq road and 18 km Shalateen-Marsa Alam Road (observations 24, 19, 23, 8, 22, 6 and 2, respectively). The results show that the activity concentration of ${ }^{226} \mathrm{Ra}$ at all locations does not exceed the worldwide average value unlike ${ }^{232} \mathrm{Th}$ and ${ }^{40} \mathrm{~K}$ concentrations (for the aforementioned locations), they are higher when compared with worldwide average values (35 Bqkg-1 for ${ }^{226} \mathrm{Ra}, 30 \mathrm{Bqkg}^{-1}$ for ${ }^{232} \mathrm{Th}^{-}$and $400 \mathrm{Bqkg}^{-1}$ for ${ }^{40} \mathrm{~K}$ ) for this radionuclide in the soil (18).

Fig. 1: Activity concentration of ${ }^{226} \mathbf{R a}$ and ${ }^{232} \mathrm{Th}$

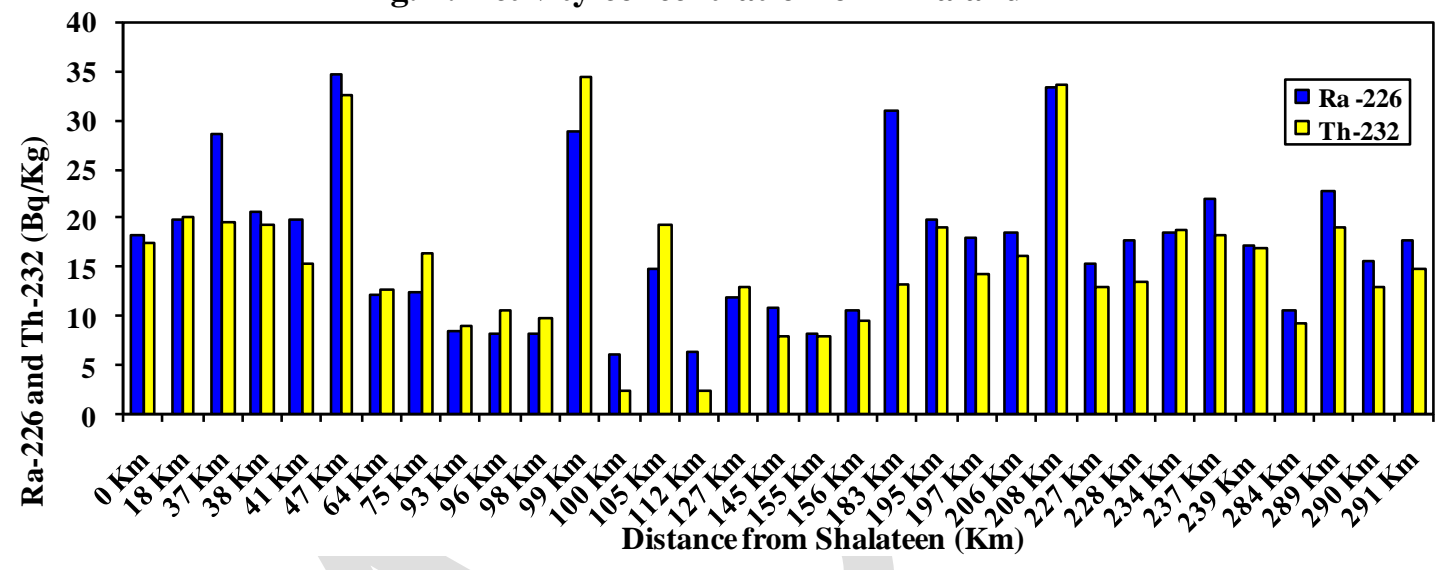

Fig. 2: Activity concentration of ${ }^{40} \mathrm{~K}$

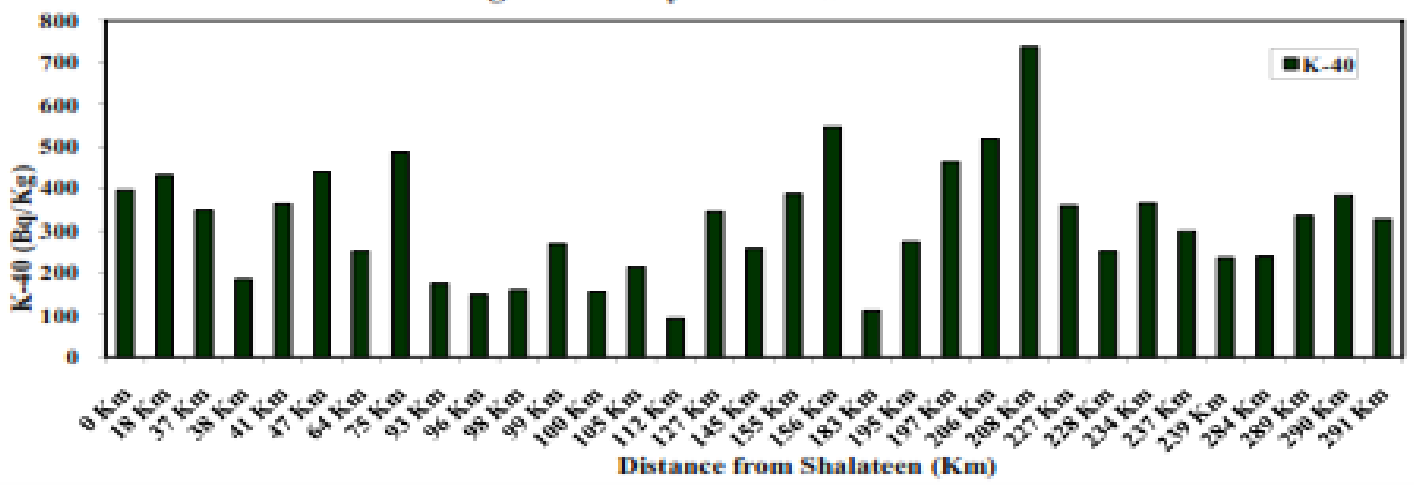

\section{Statistical Methods}

Various statistical analysis have been carried out for the radionuclides data obtained from soil sample and for the calculated radiological hazard parameters. Conventional and multivariate statistical procedures for data treatment are performed using the commercial statistics software package SPSS version 23 for Windows, MINITAB (version 15) package and Easy-Fit software. These methods were as follows:

1. Basic statistics that based on the descriptive statistics of the radionuclides and radiological hazard parameters.

2. Frequency histograms of the recorded radionuclides. 
3. Pearson's correlation coefficient for all radionuclides and radiological hazard parameters. The correlation coefficient is applied for measuring the linear dependence (correlation) between two variables.

4. Principal component analysis is applied to convert a set of observations of possibly correlated variables into a set of values of linearly uncorrelated variables called principal components (19). This analysis is applied on radionuclides and radiological hazard parameters.

5. Cluster analysis (Clustering method: Average linkage method and Ward's method) is used to identify and classify the objects of the system into groups based on their similarities and to find an optimal grouping for which the observations or objects within each group are similar, but the groups are dissimilar from each other. The analysis is done within radionuclides and radiological hazard parameters using cluster variables. Moreover, the hazard radiological parameters were followed using cluster observations. With average linkage, the distance between two clusters is the mean distance between an observation in one cluster and an observation in the other cluster. Average linkage uses a more central measure of location. With Ward's linkage, the distance between two clusters is the sum of squared deviations from points to centroids. The objective of Ward's linkage is to minimize the within-cluster sum of squares. It tends to produce clusters with similar numbers of observations, but it is sensitive to outliers (20).

\section{Conventional Statistical Analysis}

\section{RESULTS AND DISCUSSION}

Statistical tools are used to describe the statistical characteristics of radionuclides and radiation hazard parameters analyzed in soil samples. These tools include:

\subsection{Basic Statistics}

Basic descriptive statistics are used to show characteristics of the three radionuclides concentration data and radiological hazard indices in the soil of Marsa Alam-Shalateen Read-Sea coast area in Egypt. Statistical parameters such as mean, standard deviation, minimum, median, maximum, skewness, and kurtosis, are estimated and the summary presented in Table 2 . The basics statistics show that the arithmetic mean and the standard deviation of the activity concentration of ${ }^{226} \mathrm{Ra}$ and ${ }^{232} \mathrm{Th}$ are close to each other but ${ }^{40} \mathrm{~K}$ is different from that of ${ }^{226} \mathrm{Ra}$ and ${ }^{232} \mathrm{Th}$.

In probability theory and statistics the Skewness is considered as measure of the asymmetry of the probability distribution of a real-valued random variable about its mean. There are many advantages of carrying out skewness analysis of data. Many models assume normal distribution, i.e. data are symmetric about the mean. The normal distribution has skewness of zero, which is not possible in reality because experimental data points may not be perfectly symmetric. Therefore, an understanding of Skewness of a data set indicates whether deviations from the mean are going to be positive or negative. Skewness characterizes the degree of asymmetry of a distribution around its mean (21).

Table 2: Descriptive statistics of radionuclides and radiological hazard indices in the soil of Marsa AlamShalateen area.

\begin{tabular}{|c|c|c|c|c|c|c|c|c|c|c|c|}
\hline & \multicolumn{3}{|c|}{ Activities $(\mathrm{Bq} / \mathrm{Kg})$} & \multicolumn{2}{|c|}{ Dose Rates } & \multicolumn{6}{|c|}{$\begin{array}{lll}\text { Radiation } & \text { Hazarded } & \text { Indices }\end{array}$} \\
\hline Statistics & ${ }^{226} \mathrm{Ra}$ & ${ }^{232} \mathrm{Th}$ & ${ }^{40} \mathrm{~K}$ & $\begin{array}{c}\text { D } \\
\left(\mathrm{nGy} \cdot \mathrm{h}^{-1}\right)\end{array}$ & $\begin{array}{c}\text { AEDE } \\
\left(\mu \mathrm{Sv} \cdot \mathrm{y}^{-1}\right)\end{array}$ & $\begin{array}{c}\text { Raeq } \\
(\mathrm{Bq} / \mathrm{Kg})\end{array}$ & $\begin{array}{c}\mathrm{I} \gamma \mathrm{r} \\
(\mathrm{Bq} / \mathrm{Kg})\end{array}$ & $\begin{array}{c}\text { AGDE } \\
\left(\mu \mathrm{Sv} \mathrm{y}^{-1}\right)\end{array}$ & Hex & Hin & $\begin{array}{r}\operatorname{ELCRx} 10^{3} \\
\left(\mu \mathrm{Sv} \cdot \mathrm{y}^{-1}\right)\end{array}$ \\
\hline Mean & 17.20 & 15.56 & 319.2 & 30.56 & 37.48 & 63.93 & 0.4824 & 218.20 & 0.1728 & 0.2192 & 0.13117 \\
\hline StDev & 7.71 & 7.44 & 139.8 & 11.67 & 14.32 & 24.71 & 0.1847 & 83.20 & 0.0669 & 0.0853 & 0.05021 \\
\hline Minimum & 6.00 & 2.42 & 91.20 & 8.21 & 10.07 & 16.89 & 0.128 & 58.60 & 0.046 & 0.063 & 0.035 \\
\hline Variance & 59.44 & 55.35 & 19544 & 136.19 & 205.06 & 610.58 & 0.0341 & 6922.2 & 0.0045 & 0.0073 & 0.0025 \\
\hline Maximum & 34.71 & 34.50 & 736.30 & 66.52 & 81.58 & 138.52 & 1.052 & 476.20 & 0.375 & 0.465 & 0.286 \\
\hline Skewness & 0.65 & 0.93 & 0.74 & 0.69 & 0.69 & 0.68 & 0.69 & 0.69 & 0.69 & 0.65 & 0.69 \\
\hline Kurtosis & -0.100 & 1.58 & 1.08 & 2.06 & 2.06 & 1.95 & 2.08 & 2.10 & 1.94 & 1.54 & 2.06 \\
\hline
\end{tabular}


Positive skewness shows a distribution with an asymmetric long tail to the right (higher values). Negative skewness shows a distribution with an asymmetric long tail to the left (lower values). All the radionuclides have positive skewness values (Table 2) which indicate the asymmetric nature.

Kurtosis is a measure of whether the data are peaked or flat relative to a normal distribution. That is, data sets with high kurtosis tend to have a distinct peak near the mean, decline rather rapidly and have heavy tails (leptokurtic distribution). Data sets with low kurtosis tend to have a flat top near the mean rather than a shark peak and small tails (platykurtic distribution). Positive kurtosis indicates a peaked distribution and negative kurtosis indicates a flat distribution (22). In this study, ${ }^{40} \mathrm{~K}$ and ${ }^{232} \mathrm{Th}$ have positive kurtosis showing a peaked distribution while ${ }^{226} \mathrm{Ra}$ has negative kurtosis showing a flat distribution.

It is obvious from Table 2 that the average value of ${ }^{226} \mathbf{R a},{ }^{232} \mathbf{T h}$ and ${ }^{40} \mathbf{K}$ are lower than worldwide average values (35 Bqkg-1 for ${ }^{226} \mathrm{Ra}, 30 \mathrm{Bqkg}^{-1}$ for ${ }^{232} \mathrm{Th}$ and $400 \mathrm{Bqkg}^{-1}$ for ${ }^{40} \mathrm{~K}$ ) (18). There are some locations have ${ }^{232} \mathrm{Th}$ and ${ }^{40} \mathrm{~K}$ concentration values greater than the average world value as shown in Figure 2.

Absorbed Gamma Dose Rate $\left(\mathbf{D} \mathrm{nGyh}^{-1}\right)$ values range between 8.21 and $66.52 \mathrm{nGyh}^{-1}$ with the mean value of $30.56 \mathrm{nGy} \mathrm{h}^{-1}$. The estimated mean value of $D\left(\mathrm{nGyh}^{-1}\right)$ in the studied samples is lower than the world average (populated-weighted) absorbed gamma dose rate of $57 \mathrm{nGy} \mathrm{h}^{-1}(18)$. There is one location has a value exceeds the world average value (Marsa Alam-Shelateen Road Km 33 (observation 24)).

Annual Effective Dose Equivalent (AEDE $\mu \mathrm{Sv}_{\mathrm{y}} \mathrm{y}^{-1}$ ) values ranged between 10.07 and $81.58 \mu \mathrm{Svy}^{-1}$ with mean value of $37.48 \mu \mathrm{Svy}^{-1}$. The mean annual effective dose calculated in this study is much lower than the maximum permissible value for public $1000 \mu \mathrm{Svy}^{-1}(23)$.

Radium Equivalent Activity values $\left(\mathbf{R a e q ~}_{\mathrm{Bqkg}}{ }^{-1}\right)$ for the soil samples varied from $16.89 \mathrm{Bqkg}^{-1}$ to $138.52 \mathrm{Bqkg}^{-1}$ with an average value of $63.934 \mathrm{Bqkg}^{-1}$. It is noteworthy that all of the Raeq values are not exceeding the maximum permissible limit of $370 \mathrm{Bqkg}^{-1}(18)$.

Gamma Radiation Representative Level Index $\left(\mathbf{I} \gamma \mathbf{r} \mathrm{Bqkg}^{-1}\right)$ varies from 0.128 to 1.052 with mean value of 0.4824 which does not exceed the maximum permissible value (unity) (18). Moreover, I $\gamma \mathrm{r}$ in all the locations studied do not exceed the maximum permissible value (unity) (18) except one location that has exceeding value but the overtaking is very slight likewise is considered negligible. Therefore, the area is not radiologically hazardous.

The gonads, the bone marrow and the bone surface cells are considered as organs of interest by UNSCEAR (2000) (18) because of their sensitivity to radiation. An increase in Annual Gonadal Equivalent Dose (AGED $\mu$ Sv $\mathrm{y}^{-1}$ ) has been known to affect the bone marrow, causing destruction of the red blood cells that are then replaced by white blood cells. This situation results in a blood cancer called leukemia which is fatal (24). AGED is ranged between 58.60 and 476.20 with mean value of $218.20 \mu \mathrm{Sv} \mathrm{y}^{-1}$. This mean value is lower than the world average acceptable value of $3 \times 10^{2} \mu \mathrm{Sv} \mathrm{y}^{-1}(18)$. So overall there is no threat to the bone marrow and bone surface for the residents of the study area, but specifically there are some locations, which are confined in Marsa Alam-Shelateen Road Km 33, 10 km Al- Gaheliya-Abraq road and $47 \mathrm{~km}$ Baranis-Aswan Road, exceeded the world average value (See Table 1: observations 24,6 and 12). That is due to the maximum values of ${ }^{226} \mathrm{Ra},{ }^{232} \mathrm{Th}$ and ${ }^{40} \mathrm{~K}$ recorded in these locations.

External hazard index (Hex) and internal hazard index (Hin) is used to evaluate external exposure to gamma radiation in outdoor air and internal exposure to radon, respectively. The external and internal hazard index is obtained from $\mathrm{Ra}_{\mathrm{e}}$ expression through the supposition that its allowed maximum value equal to unity $(25,26)$ corresponds to the upper limit of Raeq $(370 \mathrm{~Bq} \mathrm{~kg}$ ). From Table 3 the calculated Hex varies from 0.046 to 0.375. The mean value of Hex (0.1728) is lower than unity. In addition, the calculated internal hazard index Hin varies from 0.063 to 0.465 with mean value of 0.2192 , which is also lower than the unity. Therefore, these areas are not pose radiological health risk due to exposure to ionizing radiation from the natural radionuclides in the soil.

Excess Life Cancer Risk (ELCR $\mu \mathrm{Sv} \mathrm{y}^{-1}$ ) is the probability of developing cancer over a lifetime at a given exposure level. A higher value of ELCER implies higher probability induction of cancer of the individual that is exposed (24). ELCR calculated varies from $0.035 \times 10^{-3}$ to $0.286 \times 10^{-3}$ with an average value of $0.13117 \times 10^{-3}$ which is lower than the world average permissible value of $0.29 \times 10^{-3}(27)$. 


\subsection{Frequency Histograms}

The frequency distributions of all the radionuclides $\left({ }^{226} \mathrm{Ra},{ }^{232} \mathrm{Th}\right.$ and $\left.{ }^{40} \mathrm{~K}\right)$ are plotted, and the histograms are given in Figs. 3-5. Positive skewness indicates a distribution with an asymmetric tail extending toward positive values. These asymmetric distributions of some radioactive variables such as concentrations of all measured radionuclides are shown in Figs. 3-5. The graphs for ${ }^{226} \mathrm{Ra},{ }^{232} \mathrm{Th}$ and ${ }^{40} \mathrm{~K}$ show that the skewness of these radionuclides depicts the degree of asymmetry of a distribution around its mean. These radionuclides exhibit some degree of multi-modality. This multi-modal feature of the radioactive elements demonstrates the complexity of minerals in soil samples. However, ${ }^{40} \mathrm{~K}$-graph shows that these radionuclides demonstrate a normal (bellshaped) distribution. Only ${ }^{226} \mathrm{Ra}$ has a negative kurtosis, which shows a relatively flat distribution.
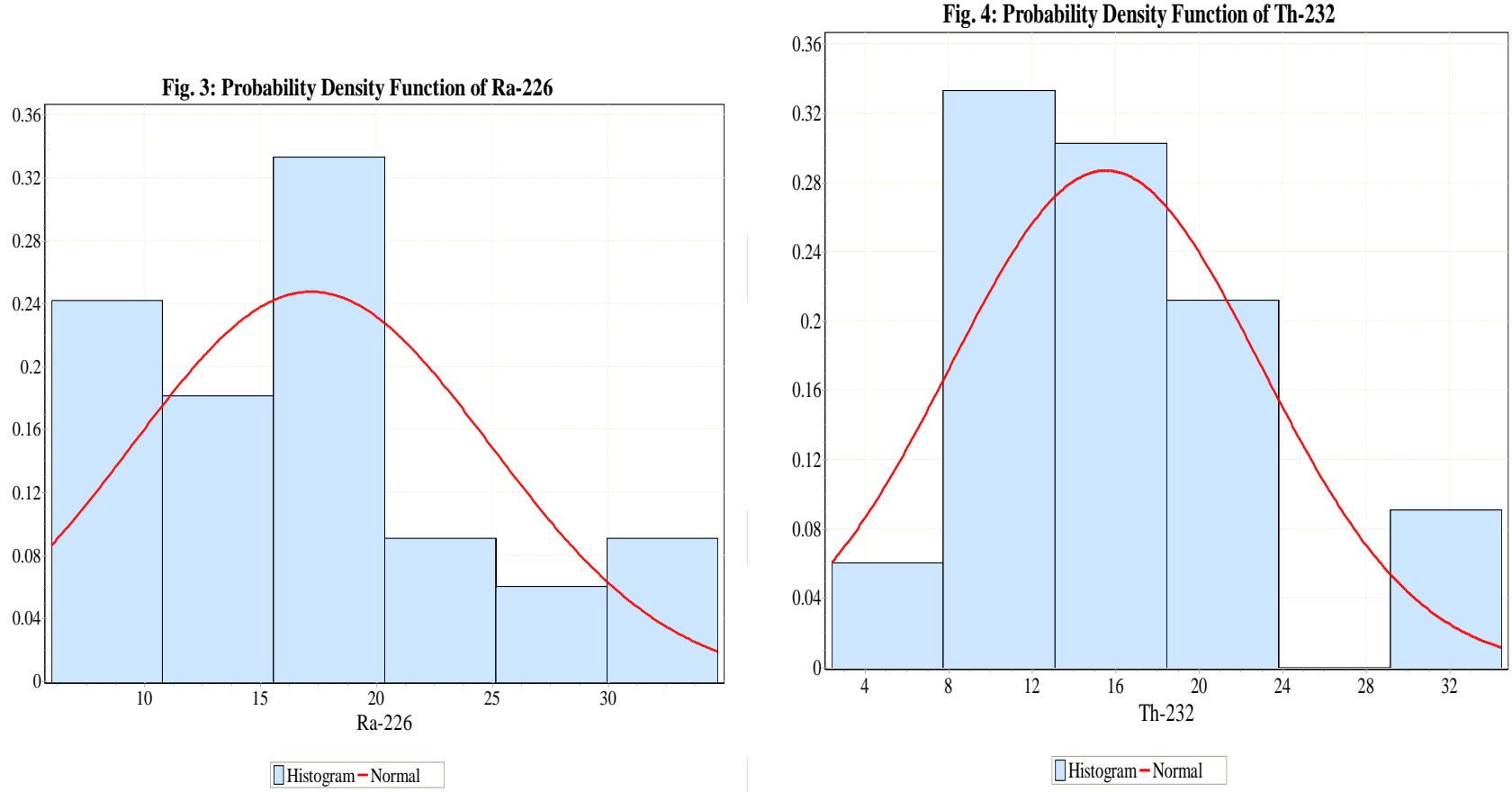

Fig. 5: Probability Density Function of K-40

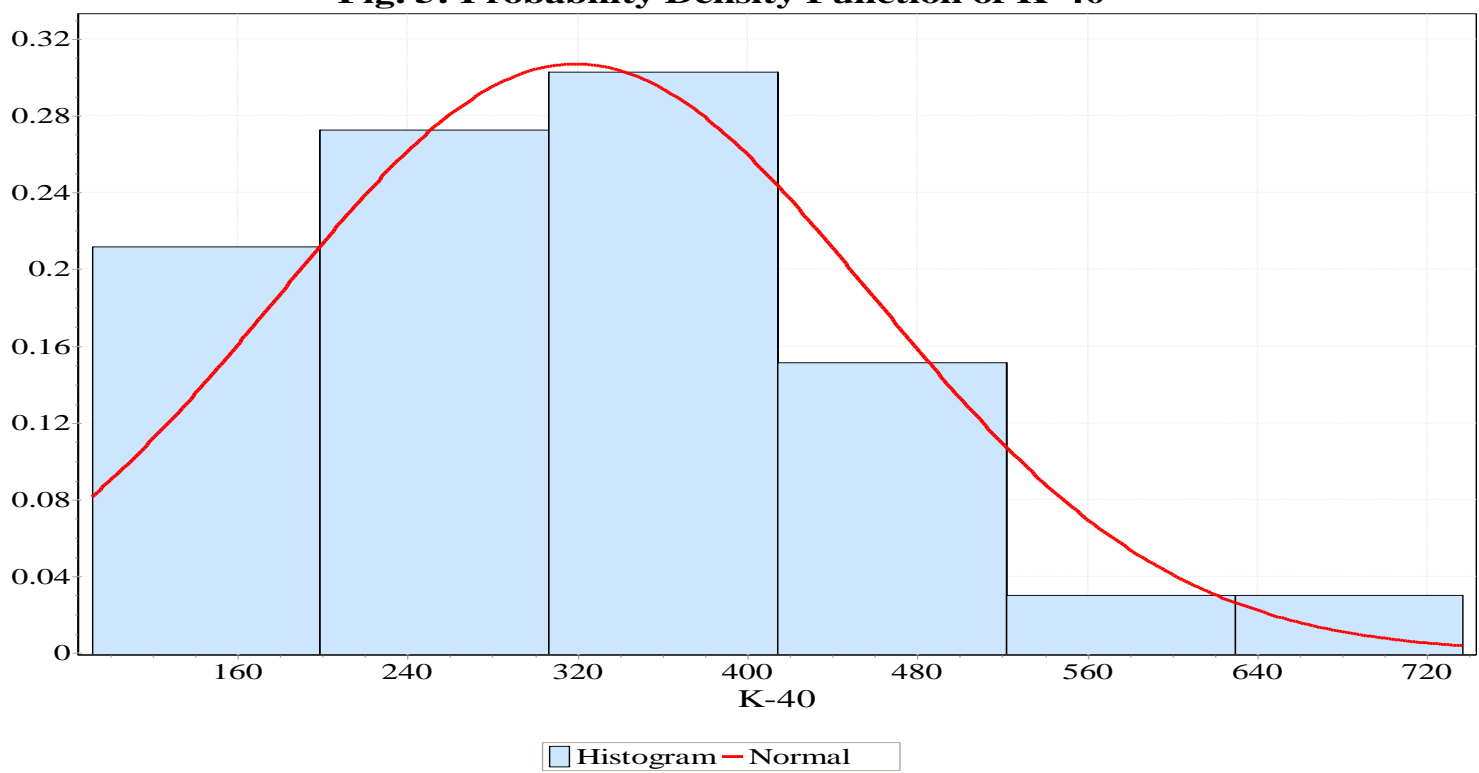




\section{Multivariate Statistical Analysis}

The intention underlying the use of multivariate analysis is to achieve great efficiency of data compression from the original data, and to gain some information useful in the interpretation of the data. This method can also help to simplify and organize large data sets to provide meaningful insight, and can help to indicate natural associations between samples and/or variables thus highlighting the information not available at first glance (28). Multivariate analysis such as principal component analysis (PCA), and cluster analysis is used to explain the correlation amongst a large number of variables in terms of a small number of factors without losing much information.

Pearson correlation, Principal Component Analysis (PCA) and Cluster analysis are carried out in order to clarify the relationship among the variables, especially the influence of soil parameters on the distribution of natural radionuclides. Cluster analysis is a useful statistical method that presents visually the degree of association among variables. The distance axis displays the degree of association between groups of variables, i.e., the lower the value on the axis, the more significant correlation (29).

\subsection{Pearson's Correlation Coefficient Analysis}

To understand reciprocal relationships and degree of association that may exist among the measured radiological parameters are assessed using Pearson's correlation coefficient analysis and the results are given in Table 3 as linear correlation matrix. From the Table, strong positive correlation is observed to exist between the three radionuclides and all the radiation hazard parameters. Similar trend has been reported by Ononugbo C. P et al. (2016) (24). Hence, these relationships show that all three radionuclides contribute to the emission of gamma radiation in all locations. Strong correlations are, however, observed between ${ }^{226} \mathrm{Ra}$ and ${ }^{232} \mathrm{Th}$ while weak one is noticed between ${ }^{40} \mathrm{~K}$ and each of ${ }^{226} \mathrm{Ra}$ and ${ }^{232} \mathrm{Th}$. It is also found that a very strong correlation between all radiation hazard parameters. It is obvious from the Table that the correlation values between radiation hazard parameters and ${ }^{232} \mathrm{Th}$ are higher than the correlation values between radiation hazard parameters and ${ }^{226} \mathrm{Ra}$. As well as, ${ }^{40} \mathrm{~K}$ gives correlation values less than ${ }^{232} \mathrm{Th}$ and ${ }^{226} \mathrm{Ra}$. That means, ${ }^{232} \mathrm{Th}$ has effects that are more powerful in radiation hazard results than ${ }^{226} \mathrm{Ra}$ and ${ }^{40} \mathrm{~K}$, respectively.

Table 3: Pearson correlation coefficient matrix of the 11 elements for the soils in the Red-Sea

\begin{tabular}{|c|c|c|c|c|c|c|c|c|c|c|c|}
\hline $\begin{array}{c}\text { Radiological } \\
\text { parameters }\end{array}$ & Ra-226 & Th-232 & K-40 & Raeq & I $\gamma \mathrm{r}$ & D & AGDE & AEDE & Hex & Hin & ELCR*10 $0^{-3}$ \\
\hline Ra-226 & 1.000 & & & & & & & & & & \\
Th-232 & 0.854 & 1.000 & & & & & & & & & \\
K-40 & 0.377 & 0.480 & 1.000 & & & & & & & & \\
Raeq & 0.850 & 0.914 & 0.765 & 1.000 & & & & & & & \\
I $\gamma \mathrm{r}$ & 0.818 & 0.889 & 0.808 & 0.998 & 1.000 & & & & & & \\
D & 0.823 & 0.888 & 0.805 & 0.998 & 1.000 & 1.000 & & & & & \\
AGDE & 0.810 & 0.879 & 0.820 & 0.996 & 1.000 & 1.000 & 1.000 & & & & \\
AEDE & 0.823 & 0.888 & 0.805 & 0.998 & 1.000 & 1.000 & 1.000 & 1.000 & & & \\
Hex & 0.851 & 0.914 & 0.764 & 1.000 & 0.997 & 0.998 & 0.996 & 0.998 & 1.000 & & \\
Hin & 0.911 & 0.925 & 0.692 & 0.992 & 0.982 & 0.983 & 0.979 & 0.983 & 0.992 & 1.000 & \\
ELCR*10-3 & 0.824 & 0.888 & 0.805 & 0.998 & 1.000 & 1.000 & 1.000 & 1.000 & 0.998 & 0.984 & 1.000 \\
\hline
\end{tabular}




\subsection{Principal Component Analysis (PCA)}

Principal component analysis (also known as factor analysis) is a multivariate statistical technique by which variables of a set of samples are linearly combined; giving rise to new fundamental components that can provide a better description and a quantitative interpretation of data (30). Factor analysis is carried out on the data set (11 variables) by applying varimax rotation with Kaiser Normalization. The rotated factor 1 and factor 2 values are reported in Table 4. The factor analysis yielded two principal components with eigen values greater than 1 . These two factors could explain over $98.7 \%$ of the total variance and leads us to the conclusion that a two factor solution will probably be adequate, and provide a reasonable summary of the data. Normally, an ordination result is good if the value is $75 \%$ or better (31). From the loading plot of factor 1 and factor 2 (Fig. 6), the first factor accounts for $57.3 \%$ of the total variance and is mainly characterized by high positive loading of concentrations of ${ }^{232} \mathrm{Th}$ and ${ }^{226} \mathrm{Ra}$. The second factor accounts for $41.4 \%$ of the total variance and mainly corresponds to high positive loading of ${ }^{40} \mathrm{~K}$.

Table 4: Rotated Component Matrix

\begin{tabular}{|c|c|c|}
\hline radiological parameters & Component 1 & Component 2 \\
\hline & & \\
Ra-226 & & \\
Th-232 & $\mathbf{0 . 9 5 0}$ & 0.190 \\
Hin & $\mathbf{0 . 9 0 3}$ & 0.333 \\
Hex & $\mathbf{0 . 8 3 8}$ & $\mathbf{0 . 5 4 3}$ \\
Raeq & $\mathbf{0 . 7 7 4}$ & $\mathbf{0 . 6 3 3}$ \\
ELCRx10 & $\mathbf{0 . 7 7 3}$ & $\mathbf{0 . 6 3 4}$ \\
AEDE & $\mathbf{0 . 7 3 2}$ & $\mathbf{0 . 6 8 1}$ \\
D & $\mathbf{0 . 7 3 2}$ & $\mathbf{0 . 6 8 1}$ \\
I $\gamma$ r & $\mathbf{0 . 7 3 2}$ & $\mathbf{0 . 6 8 2}$ \\
AGDE & $\mathbf{0 . 7 2 8}$ & $\mathbf{0 . 6 8 6}$ \\
K-40 & $\mathbf{0 . 7 1 4}$ & $\mathbf{0 . 7 0 0}$ \\
& 0.187 & $\mathbf{0 . 9 8 1}$ \\
& & \\
\hline Eignvalue & & 4.585 \\
Cotal Variance & 57.3 & 98.7 \\
\hline & 57.3 & \\
\hline & & \\
\hline
\end{tabular}

This matrix contains the loading of each variable onto each factor where values less than 0.5 are negligible from the output. The first factor seems to relate Ra-226, Th-232 and all radiological hazard parameters and there are very strong correlations between them. The second factor is related to K-40 and all radiological hazard parameters with lower correlation values than Ra-226 and Th-232. From the overall factor analysis, it can be deduced that ${ }^{232} \mathrm{Th}$ and ${ }^{226} \mathrm{Ra}$ dominantly increase the radioactivity in all sample of soil. It is clear from Table 4 that there are strongly correlated between Ra-226, Th-232 and Hin with a high loading values $(0.950,0.903$ and 0.838 , respectively). Moreover, there are the similar strong correlations between ELCR, AEDE, D and each of Ra-226 and Th-232. Likewise, similar correlations between Hex, Raeq and each of Ra-226 and Th-232 are existed. The 
second factor shows that there are strongly correlated with potassium and AGDE with a high loading value (0.981 and 0.700 , respectively). As well as, there are moderate correlations between potassium and Hin (0.981 and $0.543)$, respectively.

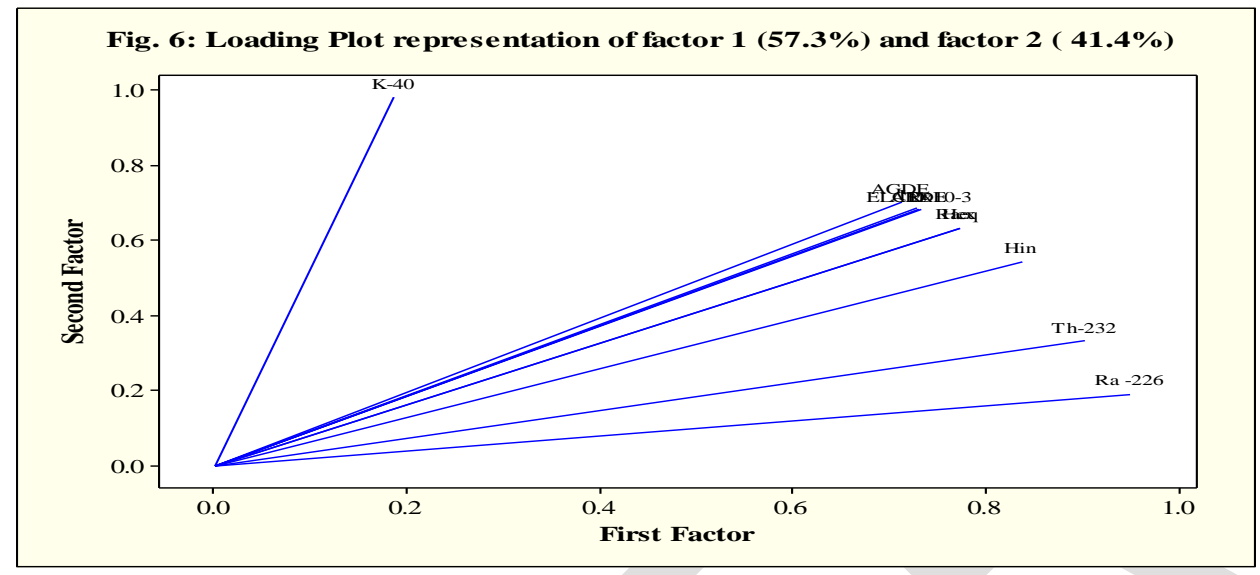

\subsection{Cluster Analysis}

Cluster analysis proved to be useful semi-quantative technique for analyzing the data and determining the linkages between soil samples from various locations.

Hierarchical Cluster Analysis (HCA) is one of multivariate statistical analysis that is used to identify and classify the objects of the system into groups based on their similarities and to find an optimal grouping for which the observations or objects within each group are similar, but the groups are dissimilar from each other (32). Similarity is a measure of distance between clusters relative to the largest distance between any two individual variables. The zero distance means the clusters are $100 \%$ similarity in their sample measurements, whereas the cluster areas are as disparate as the least similar region means similarity of $0 \%$ (31). Cluster analysis is carried out through two axes; the first is to identify similar characteristics between natural radioisotopes and radiological hazard parameters in the soil using cluster variables. The other axis is to identify similar characteristics between radiological hazard parameters in the soil using cluster observations. The results of cluster analysis are best summarized using a dendrograms (Tree Diagrams). In a dendrogram, distance is plotted on one axis, while the variables (sample units) and observations are given on the remaining axis. The tree shows how variables or observations are combined into clusters, the height of each branching point corresponding to the distance at which two clusters are joined. The dendrograms of HCA with Average and Ward's linkage methods are applied.

\subsubsection{Cluster analysis among radionuclides and radiological hazard parameters using cluster variables Average linkage method}

Figures $7 \& 8$ show the similarity and distance dendrogram that further employed to explore the associations between radionuclides and radiological parameters (11 variables). Three clusters are distinguished. Average linkage method along with correlation coefficient distance is applied. The First cluster is primarily composed of ${ }^{226} \mathrm{Ra}$ concentrations. ${ }^{32} \mathrm{Th}$ concentrations and all radiological parameters are responsible for constructing the Second cluster. In this cluster, the radiological parameters are more related to ${ }^{232} \mathrm{Th}$ concentration levels. The second cluster also shows that Raeq and Hex are sub-grouped and closer to each other (the similarity between them is $100 \%$, i.e. 0 distances). Likewise, I $\gamma \mathrm{r}, \mathrm{D}, \mathrm{AGDE}$, AEDE and ELCRx $10^{-3}$ are subgrouped and closer to each other (the similarity between them is $100 \%$ ). Hin is joined to all radiological parameters group and nearer to ${ }^{232} \mathrm{Th}$ series data than ${ }^{232} \mathrm{Th}$ and other hazard parameters (the distances between ${ }^{232} \mathrm{Th}$ and Hin is less than ${ }^{232} \mathrm{Th}$ and other radiological parameters). ${ }^{40} \mathrm{~K}$ data have been identified in another group order far from the other radionuclides (Third cluster). This may be due to the origin of ${ }^{40} \mathrm{~K}$ which is primordial single occurrence radioisotope. The cluster analysis reveals that the concentrations of ${ }^{232} \mathrm{Th}$ are more related to all the radiological parameters levels in the study area. ${ }^{226} \mathrm{Ra}$ concentrations are nearer to ${ }^{232} \mathrm{Th}$ than ${ }^{40} \mathrm{~K}$ 
concentrations. This is due to the distance between ${ }^{226} \mathrm{Ra}$ and ${ }^{232} \mathrm{Th}$ clusters are closed to each other than ${ }^{40} \mathrm{~K}$ cluster. As well as, ${ }^{226} \mathrm{Ra}$ concentrations follow ${ }^{232} \mathrm{Th}$ concentrations in terms of their correlation with the radiological parameters levels. ${ }^{40} \mathrm{~K}$ concentrations have the least linked to the radiological parameters. The correlation matrix Table confirms these results of clusters as shown in Table 3. Figures $7 \& 8$ show the similarity and the differences between radionuclides and radiological parameters.

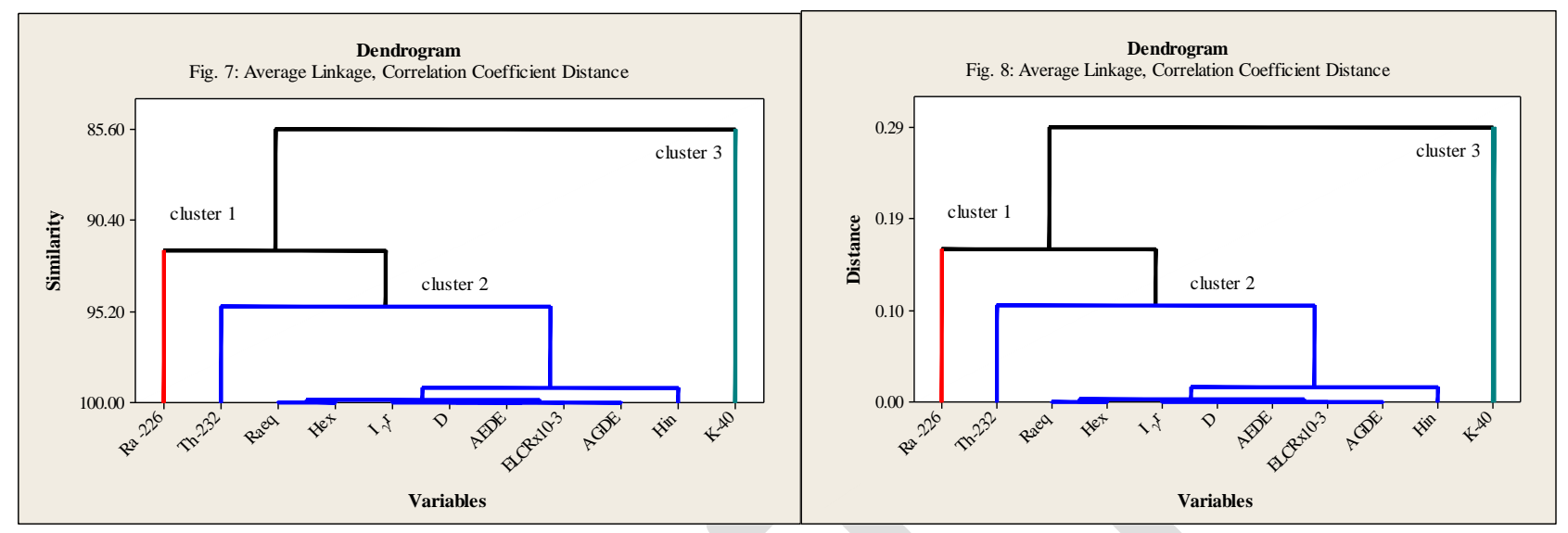

\section{Ward's linkage method}

Figures $9 \& 10$ also show the similarity and distance dendrogram that further employed to explore the associations between radionuclides and all radiological parameters. Three clusters are distinguished. Ward's linkage method along with correlation coefficient distance is applied. The First cluster is primarily composed of ${ }^{226} \mathrm{Ra}$ and ${ }^{232} \mathrm{Th}$ concentration levels and is more related to each other. All radiological parameters are responsible for constructing the Second cluster. In this cluster, Raeq and Hex are sub-grouped and is obviously more related to each other (the similarity between them is $100 \%$ (0 distances)). As well as, I $\gamma \mathrm{r}$, D, AGDE, AEDE and ELCRx $10^{-3}$ are sub-grouped and are closer to each other (the similarity between them is $\left.100 \%\right)$. Hin is joined to all radiological parameters group and its level is more related to ${ }^{226} \mathrm{Ra}$ and ${ }^{232} \mathrm{Th}$ series data (cluster 1) than other hazard parameters and cluster 1 (the distances between cluster 1 and Hin is less than the same cluster and other radiological parameters). ${ }^{40} \mathrm{~K}$ concentration levels have been identified in another cluster order far from the other radionuclides (Third cluster). These clusters analysis reveal that the concentrations of ${ }^{226} \mathrm{Ra}$ and ${ }^{232} \mathrm{Th}$ are more related to all the radiological parameters data than ${ }^{40} \mathrm{~K}$ concentrations in the study area. This is due to the fact that the distances between ${ }^{226} \mathrm{Ra} \&{ }^{232} \mathrm{Th}$ series data (cluster 1) are closed to radiological parameters group (cluster 2) than ${ }^{40} \mathrm{~K}$ cluster. Consequently, ${ }^{40} \mathrm{~K}$ concentrations have the least correlation with the radiological parameters levels. Figures $9 \& 10$ show the similarity and the differences between distances of radionuclides and radiological parameters.

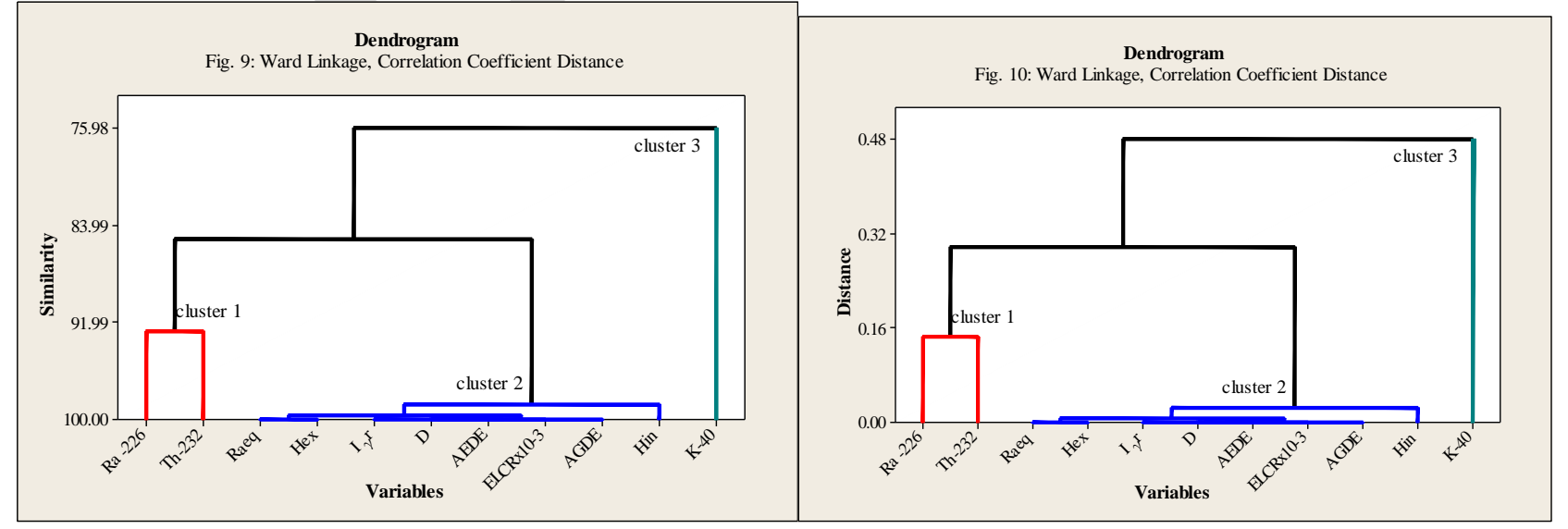




\subsubsection{Cluster analysis among hazard radiological parameters using cluster observations}

\section{Average linkage method}

Figure 11 shows dendrogram hazard radiological parameters observations along the Egyptian Red-Sea Coast. The location of each observation is illustrated in Table (1). The Average method along with Pearson distance is applied. In this dendrogram, all observations are grouped into five statistically significant clusters. Cluster 1 consists of 21 hazard radiological parameters observations. This cluster includes five sub-groups. Observations 1, 27, 22, 8 and 31 are closer to each other in their radiation hazard levels and are represented in one sub-group. Similarly, observations 5, 28, 21 and 19 are closer to each other and are represented in another subgroup. Observations 2, 23 and 3 also construct one group. All previous groups are closer to each other in their hazard of radiation levels. Observations $(4,25,32,33)$ and $(14,29,26,16,20)$ are represented in two sub-groups and the radiation hazard levels of each group barely differs. Observations 6 and 12 are clustered in one group (Cluster 2). This cluster shows that the levels of hazard radiation in $10 \mathrm{~km} \mathrm{Al}$-Gaheliya-Abraq road are closer to radiation hazard levels in $47 \mathrm{~km}$ Baranis-Aswan Road. Cluster 3 consists of seven observations. The hazard levels in points 7 and 18 are closed together. As well, points 17 and 30 are analogical and points 9, 10 and 11 are similar. Cluster 4 joins two observations that have low radiation hazard levels (13 and 15). This can be deduced from the relatively low distance at which its cluster is joined. Marsa Alam-Shelateen Road km 33 (observation 24) is classified as unique location due to the high radiation hazard level (Cluster 5). That refers to the relatively high distance at which its cluster is joined. Cluster 2 followed cluster 5 in high radiation hazard level and followed by cluster 1 and 3. The levels of radiation hazard can be deduced from Figure (11) according each group distance.

\section{Ward's linkage method}

Figure 12 shows dendrogram hazard radiological parameters observations using the Ward's method along with Pearson application. In this dendrogram, all observations are grouped into five statistically significant clusters.

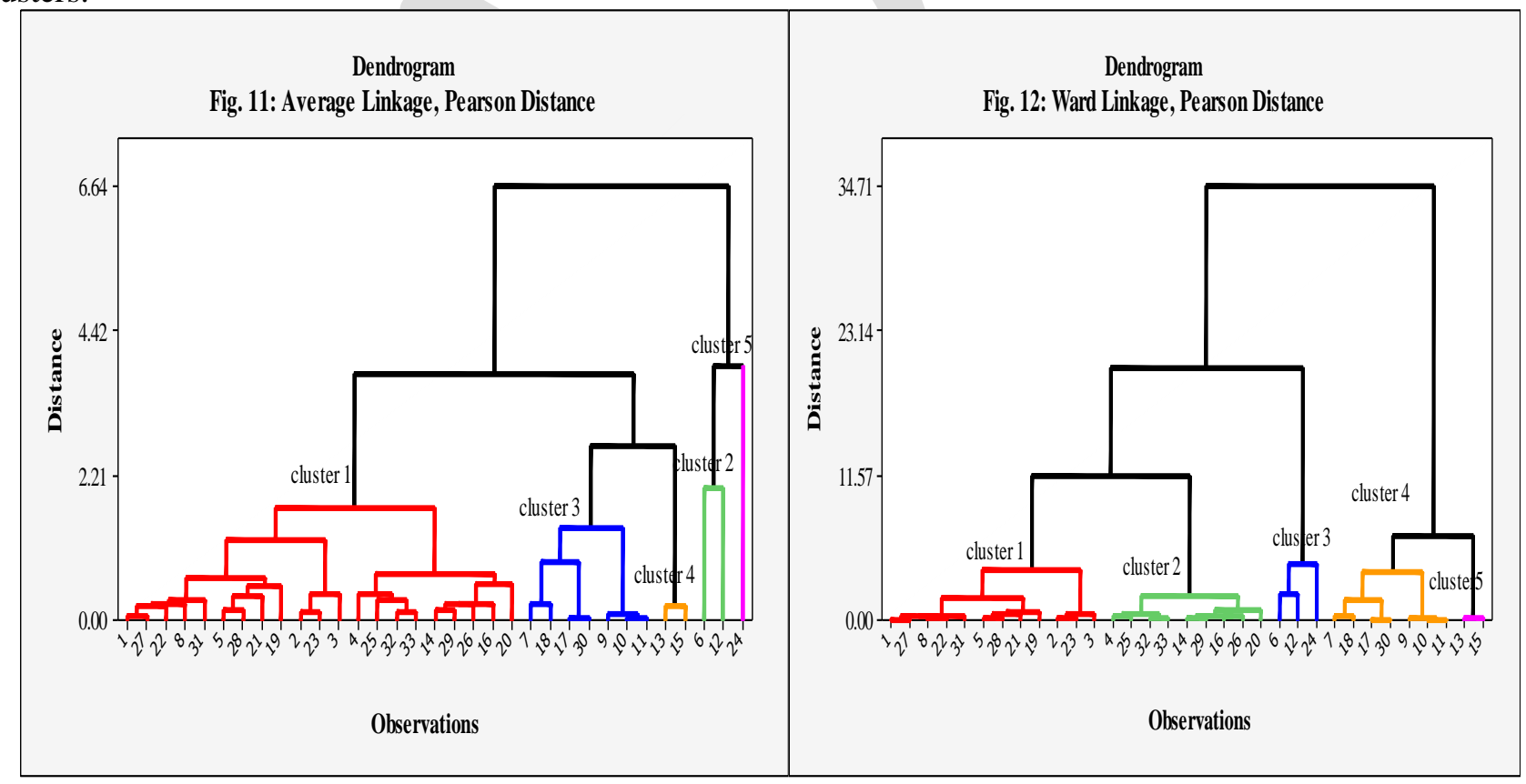

Cluster 1 consists of 12 hazard radiological parameters observations. This cluster includes three small sub-groups. Observations 1, 27, 22, 8 and 31 are closer to each other in their radiation hazard and represented in one sub-group. Similarly, observations 5, 28, 21 and 19 are nearer to each other and represented in another subgroup. Observations 2, 23 and 3 also construct one sub-group. All previous groups are closer to each other in their 
International Journal of Advanced Scientific and Technical Research $\quad$ Issue8 volume 1 January-February 2018 Available online on http://www.rspublication.com/ijst/index.html

ISSN 2249-9954

hazard of radiation. Groups $(4,25,32,33)$ and $(14,29,26,16,20)$ are clustered in two sub-groups (Cluster 2) and the radiation hazard levels of each group barely differs. Cluster 3 is composed of observations 6, 12 and 24. This cluster shows that the levels of hazard radiation in $10 \mathrm{~km} \mathrm{Al}$-Gaheliya-Abraq road are closer to radiation hazard levels in 47 km Baranis-Aswan Road. Marsa Alam-Shelateen Road km 33 (observation 24) is classified as a most location that has a high radiation hazard level. This refers to the relatively high distance at which its cluster is joined, followed by location 6 and 12. Cluster 4 consists of 7 observations. The hazard levels in locations 7 and 18 are closed together. As well, locations 17 and 30 are analogical and locations 9, 10 and 11 are similar. Cluster 5 joins two observations that have low radiation hazard levels (13 and 15). This can be deduced from the relatively low distance at which its cluster is joined. Cluster 1 followed cluster 3 in high radiation hazard levels and followed by cluster 4 and 2, respectively. The levels of radiation hazard can be deduced from Figure 12 according each group distance.

In spite of, there are differences between the two methods (Average and Ward), but the cluster analysis of both methods are considered realistic and acceptable.

\section{CONCLUSION}

The specific activity concentration of ${ }^{226} \mathrm{Ra},{ }^{232} \mathrm{Th}$ and ${ }^{40} \mathrm{~K}$ of the soil are collected from 33 districts of Marsa Alam-Shalateen area, Red Sea coast in Egypt. They had been determined using Hyper-Pure Germanium (HPGe) detector. The average of activity concentrations of these radionuclides are lower than the safe limit stipulated by UNSCEAR (2000). Strong positive correlation is observed to exist between the three radionuclides and all the radiological hazard parameters. Hence, these relationships show that all three radionuclides contribute to the emission of gamma radiation in all locations. Strong correlations are observed between ${ }^{226} \mathrm{Ra}$ and ${ }^{232} \mathrm{Th}$ while weakly correlation between ${ }^{40} \mathrm{~K}$ and each of ${ }^{226} \mathrm{Ra}$ and ${ }^{232} \mathrm{Th}$. It is also found that a very strong correlation between all radiation hazard parameters. The correlation values between radiation hazard parameters and ${ }^{232} \mathrm{Th}$ are higher than the correlation values between radiation hazard parameters and ${ }^{226} \mathrm{Ra}$. As well as, ${ }^{40} \mathrm{~K}$ gives correlation values less than ${ }^{232} \mathrm{Th}$ and ${ }^{226} \mathrm{Ra}$. The result indicates that the average value of each radiological hazard parameters are lower than the world average value reported in UNSCEAR. It implies therefore that there is no potential radiological health hazard associated with the soil samples of Marsa Alam-Shalateen area. Specifically there are some locations have Annual Gonadal Equivalent Dose (AGED) values that exceed the world average value.

The statistical method employed also revealed that the concentrations of ${ }^{232} \mathrm{Th}$ and ${ }^{226} \mathrm{Ra}$ are more related to the all the radiological parameters levels than ${ }^{40} \mathrm{~K}$ concentrations, respectively. In addition, there are three regions have high level concentrations which are confined in Marsa Alam-Shelateen Road Km 33, 10 km Al- Gaheliya-Abraq road and $47 \mathrm{~km}$ Baranis-Aswan Road. It is therefore recommended to focus on further study at these locations and the area that surround them. The result of this study could be helpful in radiological mapping of the area that has high concentrations as well as to be a baseline data for future studies.

\section{REFERENCES}

1- UNEP, "Assessment of Land-based Sources and Activities Affecting the Marine Environment in the Red Sea and Gulf of Aden", UNEP Regional Seas Reports and Studies No.166, 1997.

2- PERSGA, "Status of the Living Marine Resources in the Red Sea and Gulf of Aden Region and their Management", 2000.

3- El- Mamoney M.H. and Khater A. E. M., "Environmental Characterization and Radio-ecological Impacts of Non-Nuclear Industries on the Red Sea Coast", Journal of Environmental Radioactivity, 73(2), pp. 151-68, 2004. 
4- Abril J.M. and Abdel-Aal M.M., "Marine Radioactivity Studies in the Suez Canal. A Modelling Study on Radionuclide Dispersion", Journal of Environmental Radioactivity, Volume 48, Issue 3, pp. 261-386, 2000.

5- Al -Moubaraki A.H., Al-Judaibi A. and Asiri M., "Corrosion of C-Steel in the Red Sea: Effect of Immersion Time and Inhibitor Concentration", International Journal of ELECTROCHEMICAL SCIENCE, 10, pp. 4252-4278, 2015.

6- Saudi Arabia Plans a Huge Red Sea Beach Tourism Project, 2017. available online: https://www.bloomberg.com/news/articles/2017-08-01/saudi-arabia-unveils-plans-for-mega-red-seatourism-project.

7- Hawkins J.P. and Roberts C.M., "The Growth of Coastal Tourism in the Red Sea: Present and Possible Future Effects on Coral Reefs". In: R.N. Ginsburg Proceedings of the Colloquium on Global Aspects of Coral Reefs, Health, Hazards and History, University of Miami, Florida, pp.385-391, 1993.

8- Hanna R.G.M, "The Level of Heavy Metals in the Red Sea after 50 Years", Science of the Total Environment, 125, pp. 417-448, 1992.

9- Ahmed, N.K., Abbady A., El-Arabi A.M., Mitchel R., El-Kamel, A.H and Abbady A.G.E, "Comparative Study of Natural Radioactivity of Some Selected Rocks from Egypt and Germany", Indian Journal of Pure and Applied Physics, Vol. 44, pp. 209-215, 2006.

10- Harb S., El-Kamel A.H., Abd El-Mageed A.I., Abbady A. and Rashed W., "Concentration of U-238, U235, Ra-226, Th-232 AND K-40 for Some Granite Samples in Eastern Desert of Egypt”,. In Proceedings of the 3rd environmental physics conference, 19-23, Aswan, Egypt, 2008.

11- Yousef H.A., \& Saleh G.M., "Measurement of the Natural Radioactivity in Cataclastic Rock Samples Using RS-230 Spectrometer", Greener Journal of Physical Sciences, 3(5), pp. 165-176, 2013.

12- Abdel-Razek Y.A., Bakhit A.F., and Nada A.A., "In Measurements of the Natural Radioactivity Along Wadi Nugrus, Egypt", IX Radiation Physics \& Protection Conference, Nasr City, Cairo, Egypt, pp. 225$231,2008$.

13- EL-Saharty A.A. and Dar M.A., "The Concentration Levels of Some Iisotopic Radionuclides in the Coastal Sediments of the Red Sea, Egypt", Isotope \& Radiation Residence, 42(1), pp. 11-27, 2008.

14- El-Taher A. and Madkour A., "Distribution and Environmental Iimpacts of Metals and Natural Radionuclides in Marine Sediments Iin-front of Different Wadies Mouth along the Egyptian Red Sea Coast". Applied Radiation and Isotopes, 69, pp. 550-558, 2011.

15- Salam, M.H.M., "Assessment of Radioactive and Chemical Pollutants in Water and Sediments of the Egyptian Red Sea Coast”, Ph.D. Thesis, Faculty of science, Zagazig Univ., 156p, 2012.

16- Arafat A.A., Salama M.H.M., El-Sayed S.A. and Elfeel A.A., "Distribution of Natural Radionuclides and Assessment of the Associated Hazards in the Environment of Marsa Alam-Shalateen area, Red Sea coast, Egypt”, Journal of Radiation Research and Applied Sciences, Vol. 10, Issue 3, pp. 219-232, 2017.

17- Baha El Din S.M., “ Important Bird Areas in Africa and associated islands - Egypt”, pp. 241-264, 2001. available online: http://www.birdlife.org.

18- UNSCEAR (United Nations Scientific Committee on the Effects of Atomic Radiation), "Sources and effects of ionizing radiation", United Nations, New York, Report to the General Assembly with Annexes. 2000.

19- Wikipedia, Principal component analysis, 2017.

En.wikipedia.org, available online: https://en.wikipedia.org/wiki/Principal_component_analysis.

20- MINITAB User's Guide 2: "Data Analysis and Quality Tools", Release 13 for Windows®, Minitab Inc. 2000.

21- Groeneveld R.A. and Meeden G., "Measuring skewness and kurtosis”. The Statistician 33 (4), pp. 391399, 1984.

22- Maimon O.Z. and Rokach L., "Decomposition Methodology for Knowledge Discovery and Data Mining: Theory and Applications", World Scientific publishing Co. Pte. Ltd., copyright 2005.

23- ICRP (International Commission on Radiological Protection), "Recommendations of the International Commission on Radiological Protection”, ICRP Publication 60 Ann, 1990. 
24- Ononugbo C.P., Avwiri G.O. and Tutumeni G., "Measurement of Natural Radioactivity and Evaluation of Radiation Hazards in Soil of Abua/Odual Districts Using Multivariate Statistical Approach", British Journal of Environmental Sciences, Vol.4, No.1, pp. 35-48, 2016.

25- UNSCEAR (United Nations Scientific Committee on the Effects of Atomic Radiation), "Sources, effects and risks of ionizing radiation", United Nations, New York, Report to the General Assembly with Annexes, 1988.

26- Beretka J., and Mathew P.J., "Natural radioactivity of Australian building materials, industrial wastes and by-products": Health Physics 48, pp. 87-95, 1985.

27- Taskin H., Karavus M., Ay P., Topuzoglu A., Hidiroglu S. and Karahan G., "Radionuclide concentration in soil and lifetime cancer risk due to the gamma radioactivity in Kirklareli, Turkey", Journal of environmental radioactivity, 100, pp. 49-53, 2009.

28- Sivakumar S., Chandrasekaranb A., Ravisankarc R., Ravikumarc S.M., Prince Prakash Jebakumard J., Vijayagopale P., Vijayalakshmie I. and Jose M.T., "Measurement of Natural Radioactivity and Evaluation of Radiation Hazards in Coastal Sediments of East Coast of Tamilnadu Using Statistical Approachs", Journal of Taibah University for Science, Vol. 8, pp. 375-384, 2014.

29- SureshGandhi M., Ravisankar R., Rajalakshmi A., Sivakumar S., Chandrasekaran A. and Pream Anand D., "Measurements of Natural Gamma Radiation in Beach Sediments of North East Coast of Tamilnadu, India by Gamma Ray Spectrometry with Multivariate Statistical Approach", Journal of Radiation Research and Applied Sciences, Vol. 7, Issue 1, pp. 7-17, 2014.

30- Ravisankar R., Vanasundari K., Suganya M., Raghu Y., Rajalakshmi A., Chandrasekaran A., Sivakumar S., Chandramohan J., Chandramohan J., Vijayagopal P. and Venkatraman B., "Multivariate Statistical Analysis of Radiological Data of building materials used in Tiruvannamalai, Tamilnadu, India", Applied Radiation and Isotopes, Vol. 85, pp. 114-127, 2014.

31- Tsai T.L., Liu C.C, Chuang C.Y., Wei H.J. and Men L.C., "The Effects of Physico-Chemical Properties on Natural Radioactivity Levels, Associated Dose Rate and Evaluation of Radiation Hazard in the Soil of Taiwan Using Statistical Analysis", Journal of Radioanalytical and Nuclear Chemistry, 288:927-936, 2011.

32- Senthilkumar R.D., Narayanaswamy R., "Assessment of Radiological Hazards in the Industrial Effluent Disposed Soil with Statistical Analyses", Journal of Radiation Research and Applied Sciences, Vol. 9, Issue 4, pp. 449-456, 2016. 